\title{
Masculinities, Violence and Communitarian Control
}

\section{John Braithwaite and Kathleen Daly}

Violence is gendered: it is in considerable measure a problem and consequence of masculinity. Contemporary state interventions to control violence are no less gendered: structures of response, from arrest through imprisonment, glorify tough cops, celebrate adversarial relations, and construct a virtuous "protective" state by incarcerating or, in some countries, killing "the bad guys". What alternatives are possible in an apparently closed system, where masculinity and masculinist structures are both the cause and putative cure of violence?

In this essay, we consider men's violence toward women and ways of responding to it. Recognising the failure of traditional justice system responses toward violent men, we outline a more promising approach, one compatible with the principles and visions of republican criminology (Braithwaite 1989; Braithwaite \& Pettit 1990). This approach uses a community conference strategy adapted from the Maori culture in New Zealand as a key element in an overall regulatory ideal that repudiates exploitative masculinities (see Mugford \& Mugford 1992). We elucidate the community conference, discuss its strengths, and address vexing questions about its efficacy in different contexts.

\section{Multiple Masculinities and Normal Violence}

Multiple masculinities are implicated in the gendered patterning of violence. Men's violence toward men involves a masculinity of status competition and bravado among peers (Daly \& Wilson 1988; Luckenbill 1977; Polk \& Ranson 1991). Men's rape and assault of women reflect a masculinity of domination, control, humiliation, and degradation of women (Brownmiller 1975; Wilson 
1978; MacKinnon 1987; Smith, 1990; Alder 1991; Snider 1992). Other types of harm involve a shameless masculinity or a masculinity of unconnectedness and unconcern for others. When called to account for exploitative conduct, men's responses may be rage rather than guilt, or an amplification of noncaring identities such as "badass" (Braithwaite 1991; Katz 1988; Miedzian 1991; Retzinger 1991). Some women may exhibit these masculine qualities, but their behaviour would likely be interpreted as pathology. They would derive little support for expressions of masculine violence from even the most marginal of subcultures.

For men, status competition through physical force, domination-humiliation of the less powerful, and knowing no shame have substantial cultural support. Few societies today contain majoritarian masculinity that sets its face against violence. In general, women's and men's social movements have failed to nurture credible competing non-violent identities for heterosexual men (see Carrigan et al. 1985; Connell 1987). When such identities are imagined or promoted, they are confined to men's potential to care for others in families, that is, to be loving or caring fathers, husbands, sons, or brothers. In fact, the caring masculine identities having some cultural support are more likely found within "the family" than outside it. To suggest that masculine caring is featured in family life is expected and paradoxical. It is to be expected in light of the physical separation for men of "work" and "home" with the rise of capitalism (see Zaretsky 1976); historically, emotional life for men became centred on the home or the family "as haven" (Lasch 1977). Yet, in light of feminist research, it is paradoxical to associate masculine caring with family life. Evidence from the eighteenth and nineteenth centuries in Europe and the US shows that men exercised control over household members, including wives, children, servants, and slaves by physical force and violence, often with the support of religious and secular law (Dobash \& Dobash 1992, pp. 267-9). Contemporary research indicates that women's experiences with physical and 
sexual violence are most likely to be within intimate relationships with men including fathers, husbands, boyfriends, and other men they know. Thus, while male identities in the family are a problem, the caring sides to those identities may be part of the solution.

\section{Failures of Justice System Intervention}

The failures of traditional justice system responses to men's violence against women can be summarised in three points.

Problem 1: Most men are not made accountable for acts of rape or violence against intimates. Women do not report the incidents (Dobash \& Dobash 1979, pp. 164-7; Estrich 1987, pp. 13, 17; Temkin 1987, pp.

10-12; Stanko 1985; Dutton 1988, p. 7; Smith 1989). There are also perceived evidentiary difficulties or police indifference leading to non- prosecution (Chappell \& Singer 1977; Edwards 1989, pp. 100-6, 172-3 ; Frohmann 1991; Hatty 1988; Temkin 1987, pp. 12-15; Buzawa \& Buzawa 1990, p. 58; Stith 1990; Zorza 1992, p. 71), plea bargaining, and acquittals (Kalven \& Zeisel 1966, pp. 249-54; Adler 1987, p. 121; Temkin, 1987, p. 15).

Problem 2: The men who are arrested and prosecuted for violence against women may have escaped retribution before and may have entrenched patterns of raping and assaulting women. This follows from the evidence cited under Problem 1. When criminal conviction is a rare event for perpetrators, repeat offenders will often be hardened by the time of their first conviction. Because they are hardened offenders, rehabilitation programs fail. They fail because they are attempted when a history of violence is so advanced; they fail because the prison that is seen as necessary for a hardened criminal is the least likely site for rehabilitation; and they fail because they occur in a context where a man is stigmatised as a fiend when he believes that he has been a normal (violent) male for many years. 
Problem 3: Women victimised by men's violence are re-victimised by engaging the criminal process. Complainants of intimate assaults may not be taken seriously by the police or courts (Stanko 1982; Ferraro 1989; Stanko 1989). Rape victims (or survivors) feel ashamed of coming forward and pursuing a complaint (Dobash \& Dobash 1979, p. 164; Newby 1980, p. 115; Scutt 1983, p. 166; Stanko 1985, p. 72). The criminal process silences the victim. If the case goes to trial, the woman is denied the chance to tell her story in her own way. Rather, she becomes evidentiary fodder for a defence attorney. She is not allowed to tell the offender what she thinks of him, what he has done to her life. She has no opportunity to say what she thinks should happen to the man (Smart 1990; Real Rape Law Coalition 1991), and there is no ceremony to clear her character (Smart 1989).

For rape, the reform literature tends to concentrate on evidentiary rules at trial. Some feminists have become disillusioned with the possibility of changing rape law and procedure; they urge that energies be focused on the bigger battles against patriarchal structures rather than be dissipated on the minutiae of liberal legalism (Smart 1990; Snider 1990, 1992). For domestic violence, debate has centred on the merits of the conciliation model and law enforcement model (Lerman 1984).

The limitations of liberal legalism as a reform agenda are acknowledged. Moreover, it is important that a regulatory strategy not pit law enforcement against communitarian forms of control. Justice system institutions can be reformed that give voice to women and that continue the struggle against men's domination of women. A radical shift of paradigm will be required: it will treat victims and offenders as citizens rather than as legal subjects, empower communities at the expense of judges, and confront exploitative masculinities with pro-feminist voices. It involves a shift from a liberal to a civic republican frame. 


\section{Republican Criminology}

Defended elsewhere (Braithwaite 1989, 1993; Braithwaite \& Pettit 1990), republican criminology contains the following elements and claims. Shaming is more important to crime control than punishment, and the most potent shaming is that which occurs within communities of concern. Shame has negative consequences for offenders and victims unless it is joined with a ritual termination of shame (reintegration ceremonies). The criminal process should empower communities of concern, and it should empower victims with voice and the ability to influence outcomes (Eijkman 1992). Communities of concern must negotiate social assurances that victims will be free from future predation and harm.

A reform strategy that embodies these principles, albeit in a tentative way, is the community conference. These conferences can become a key building block of a political strategy against exploitative masculinities.

\section{The Community Conference Strategy}

The idea of the community conference comes from New Zealand, where, since 1989, it has been the preferred approach in responding to juvenile crime.

White New Zealanders (or Pakeha) adapted the idea of family group conferences from Maori culture, where it has been used for centuries in responding to sexual abuse and violence in families as well as for a variety of more minor offences. Pakeha have been more cautious about applying the Maori approach in response to family violence, partly because of the legitimate concern that power imbalances among family members can easily be reproduced in family conferences.

The family group conference (FGC) approach in handling juvenile crime is as follows (see Maxwell \& Morris 1993, ch. 1). After an offence is detected by the state, a youth justice coordinator convenes a conference. Those invited are 
the offender (let us assume here a male), ${ }^{2}$ the boy's family members (often extending to aunts, grandparents, cousins), other citizens who are key supports in the boy's life (perhaps a football coach he particularly respects), the police, the victim, victim supporters, and in some instances, a youth justice advocate. These conferences can be viewed as citizenship ceremonies of reintegrative shaming (Braithwaite \& Mugford 1993). The theory of the FGC is that discussion of the harm and distress caused to the victim and the offender's family will communicate shame to the offender. The assembling of people who care about and respect the offender fosters reintegration (or healing as it is termed by the Maori) of social relationships. In a successful conference, the offender is brought to experience remorse for the effects of the crime; to understand that he or she can count on the continuing support, love, and respect of family and friends; and to agree on a plan of action to prevent further harm. All conference participants are given the opportunity to explain how the offence affected them and to put forward proposals for the plan of action. The offender and his or her family members then propose a plan, which is discussed and modified until it is agreeable to all FGC participants, including the police.

Two features of the conference maximise its potential for reintegrative shaming. Giving voice to victims and victim supporters structures shaming into the process; and the presence of offender supporters structures reintegration into the process. These features are conducive to reintegrative shaming, though they do not guarantee it.

Those familiar with the uses of mediation in domestic assault cases, or in family law more generally (Lerman 1984; Fineman 1991; Rifkin 1989), will immediately see the worry in this approach. It empowers a family structure already characterised by deep imbalances of power between men and women, abusing adults and abused children. However, traditional Maori diagnoses of power imbalance, while not feminist, bear some resemblances to a Western 
feminist analysis. For example, in some Maori tribes an accused male abuser would have no right to speak at the conference. Any statements in his defence would have to be made through someone moved to speak on his behalf. Maori responses also challenge statist solutions to crime problems. Statist thinkers see a problem of power imbalance in the family and assume state personnel (such as social workers or police officers) are the best agents for correcting that imbalance. In Maori thinking, it is members of extended families who are in a better position to intervene against abuse of family power than the social workers or police officers. Communities of care and concern such as extended families are in a better position to exercise periodic surveillance of family violence or abuse, to talk with family members to ensure they are enjoying freedom from violence, to shame family members when abuse of power does occur, to enforce agreements such as not drinking alcohol, to negotiate understandings that an abused person has a safe harbour nearby to stay (a kin member's or neighbour's house), and to negotiate the circumstances of the abuser's removal from the household until there is satisfactory assurance of violence-free family life.

Viable extended families do not exist for many abused individuals who live in Western societies. In New Zealand, the state at times has been impressively proactive on this score. If there is an aunt who has an especially loving relationship with the offender, but who lives hundreds of miles away, the state will pay for her to attend the conference. Occasionally, an agreement is reached in which an offender, who has run to the streets to escape an abusive household, can live with relatives in another community.

In 1991, a variation on the New Zealand conference strategy was implemented in Wagga Wagga (Australia), a city of 60,000 people, $100 \mathrm{~km}$ west of the capital, Canberra. It has been introduced in other Australian jurisdictions, though taking variable forms (see Alder \& Wundersitz 1994). One of the authors has observed the processing of 23 young people through conferences in 
Wagga Wagga and New Zealand during 1991-93; we shall draw from some of these conferences to illustrate its practice.

The genius of the Maori approach, as adapted in New Zealand and Australia, is that it is a particularistic individual-centred communitarianism that can work in an urban setting. The strategy does not rely on fixed assumptions of where community will be found. It does not assume that there will be meaningful community in the geographical area surrounding an offender's home. Nor does it assume that members of a nuclear family will be a positive basis of care, though it always attempts to nurture caring in families. It does not assume that members of the extended family will be caring and effective problem solvers. It does assume one thing: if a group who cares about both the offender and victim cannot be assembled, this means the conference coordinator is incompetent, not that these human beings are devoid of caring relationships. The challenge for a conference coordinator is to find the people in an offender's life who really care about him or her, wherever they are. One example of the handling of a male teenager in Wagga Wagga illustrates this point. The boy had been thrown out of his home. The coordinator discovered that his community of concern was the football team where he enjoyed respect and affection. At the football club, the coordinator asked whether the parents of other team members would be prepared to take him in for a time. Several offered. The boy chose the one he liked best but then found he did not like living there; he moved on to another set of football team parents and seemed to be happy at the second try.

Another important feature is that the conference approach is geared to a multicultural society. Anglo-Saxon liberal legalism has crushed the communitarian justice of the Celtic peoples, the Maoris, Australian Aboriginal people, native Americans, and Asian ethnic groups with a univocal imperial system that sacrifices diversity in problem-solving strategies to belief in equal treatment under one standard strategy. The community conference, in contrast, 
empowers particular communities of citizens who care about particular people to come up with unique solutions in ways that seem culturally appropriate to those people and circumstances. Western liberal legalism does have a valuable role in plural problem- solving: constitutionalising it and providing citizens with guarantees that certain human rights cannot be breached in the name of cultural integrity. Hence, when conferences are established, advocates can ring alarm bells to engage court intervention when sanctions are imposed beyond the maximum allowed according to more universal state laws. There must be methods of reviewing decisions to ensure that offenders are not coerced into admitting guilt for offences they claim not to have committed. The New Zealand state has attended to these issues in its reform agenda (Office of the Commissioner for Children 1991; Ministerial Review Team 1992). What we might aspire to is a creative blend of empowered legal pluralism constrained by Western universalist legal principles (see Braithwaite \& Pettit 1990).

\section{Community Conferences in the Regulatory Pyramid}

How would the community conference be used in responding to men's violence against women? We shall consider men who assault intimates, an estimated 10 to 33 per cent of whom also rape them (Frieze \& Browne 1989, pp. 186-90). To do so, we first sketch how community conferences articulate with other forms of state intervention including powers to arrest and punish. Republican criminology gives up on prison as the best way of responding to or containing men's violence toward women. It advocates minimalism in the use of imprisonment (Braithwaite \& Pettit 1990), but it does not advocate abolitionism. Like Dobash and Dobash (1992, pp. 210-12), we are wary of an abolitionist agenda of returning men's violence toward women to an illdefined "community", since power imbalances would reinforce patriarchal power. We are interested in the possibilities for communitarian institutions to empower victims "to use the criminal justice process to negotiate their own 
security with suspects/spouses" (Fagan \& Browne 1990, p. 190; see also Mugford \& Mugford 1992). Both mandatory arrest and abolitionism deprive victims of the discretion necessary for such negotiation. Some feminist abolitionist proposals (for example, Meima 1990) do contain an incipient conference strategy, but they do not allow for any accommodation of communitarian ideals with the option of imprisonment. If non-carceral approaches fail and if imprisonment of a violent man offers more protection of republican liberty than doing nothing, then the man should be imprisoned. We envision the regulatory ideal in the form of an enforcement pyramid (see Figure 1). The existence of imprisonment at the peak of the pyramid channels the regulatory action down to the base of the pyramid. Regulatory institutions can be designed such that state power enfeebles community control or, as in the pyramid model, so that it enables it. The republican does not call for an informalism that replaces formalism, but for a formalism that empowers and constitutionalises informalism. The preference is to solve problems at the base of the pyramid, but if they cannot be solved there, they are confronted at higher levels. By signalling a societal capability of escalating through these levels, we communicate to a violent man that he should respond by bringing his violence under control. Otherwise, he will face one escalation after another of intervention in his violent life.

At the pyramid's base, the theoretical assumption is that violence within families is least likely when family members have internalised an abhorrence of violence, when masculinity does not depend on domination to persuade, when women are not socially subordinated, and when caring for others is valued. A long historical process of community and state involvement in shaming acts of intimate violence can create a society in which most citizens internalise the shamefulness of violence. The great historical agent of this process is not families or the police, but an active women's movement. Thus, most social control can occur at the pyramid's base by self-sanctioning with 
pangs of conscience.

If self-sanctioning fails, the history of community shaming of violence can persuade an abusive man that others will disapprove of him and his violence. No one has to confront the man with shame at this level; a man who understands the culture will know that those who learn about his violence will gossip disapprovingly. When gossip hits its target, it will do so without being heard by the target; it will be effective in the imagination of a culturally knowledgeable subject (Braithwaite 1989). But if a man is incapable of imagining the disapproval others feel, then someone must confront him with that disapproval. If family members are too intimidated, then public intervention is required. Consequently, the next rung in the pyramid involves the police being called and a warrant for arrest being issued.

Warrant for arrest is preferred over actual arrest at this level because there is evidence that arrest warrants may be effective in reducing subsequent violence - at least from a set of cases where offenders were absent when the police arrived (Dunford 1990). Sherman (1992) interprets this as a "sword of Damocles" effect. It is identical to the theory of the pyramid: automatic punitiveness is inferior to signalling the prospect of future enforcement, hence channelling the regulatory game toward cooperative problem-solving (for the underlying game theory,see Ayres \& Braithwaite 1992, ch. 2). Issuing an arrest warrant, even if the man is present, is the first intervention. When the warrant is issued, the police should advise the woman to move to a shelter and seek the advice and support of a shelter advocate. The man has time to think about the "sword of Damocles" that the warrant has put in place.

However, it recognises that for some men, an arrest warrant (like a restraining or protection order) will be merely viewed as a "piece of paper" (Chaudhuri \& Daly 1992), especially for men who have been arrested before. When this is true, the remedy is escalation up the pyramid. Note also a key difference between a criminal arrest warrant and a civil restraining order. The restraining 
order enables escalation to enforcement action in the face of further misconduct; the arrest warrant enables prosecution for the violence that has already occurred in addition to enforcement directed at the further misconduct. The design, meaning, and results of the original Minneapolis police field experiment and subsequent replications continue to be debated (Sherman \& Berk 1984; Lempert 1989; Sherman 1992; Dunford 1990; Lerman 1992; Bowman 1992; Frisch 1992). Recall that the experiments randomly assigned different police "treatments" in responding to domestic violence calls: arrest, separation, and mediation. The original Minneapolis study (Sherman \& Berk 1984) revealed significant effects of arrest over separation in reducing subsequent violence. The accumulated evidence from subsequent research suggests a simple deterrence model of arrest is inaccurate. Sherman (1992) now rejects the pro-arrest conclusions drawn from his previous research. For a subset of violent men in four of the Minneapolis replications, those white and employed, he concludes that arrest seemed to have a shaming effect that reduced subsequent violence (see also Hopkins \& McGregor 1991, pp. 12530; Williams \& Hawkins 1989). But for another subset of men, those black (in three of the studies) and unemployed (in four), arrest seemed to promote rage or defiance rather than shame. For this group, arrest was another stigmatic encounter with the justice system, which increased the men's anger and violence. The stigmatic effect of arrest for the latter group was stronger than the reintegrative effect of arrest for the former; thus, across the board proarrest policies may cause more violence than they prevent. This is why we favour arrest warrants as the first state intervention; these would be followed by community conferences before moving up the enforcement pyramid to arrest (see also Bridgeforth 1990, p. 76 cited in Sherman 1993). Although arrest may subsequently escalate an abuser's violence, at the time of the incident, taking a violent man into police custody may provide an abused woman a measure of safety. There can be ways to achieve such safety without arrest. 
While the man is issued a suspended warrant by one police officer, another could take the woman aside and suggest moving to a shelter until a community conference is convened. Such a policy would mean shifting resources from police lockups under pro-arrest policies to community shelters. Although shelters are expensive, they are less costly to build and run than lockups. Another key benefit of encouraging shelters is that shelter staff are made available to abused women as caring advocates for community conferences.

The next rung of the pyramid is the conference. Several unsuccessful conferences might be held before warrants for arrest were acted upon, in the worst cases leading to prosecution and incarceration. Some may recoil at the thought of one conference failing, more violence, another failed conference, more violence still, being repeated in a number of cycles before the ultimate sanction of incarceration is invoked. But there can be considerable intervention into a violent man's life when moving from one failed conference to another. For example, there could be escalation from weekly reporting by all family members of any violent incidents to the man's aunt or brother-in-law (conference 1), to a relative or other supporter of the woman moving into the household (conference 2), to the man moving to a friend's household (conference 3).

There are many other possible ways to intervene. For example, agreement might be reached on a restructuring of the family's bank accounts so that the woman is economically empowered to walk out if she faces more violence. The conference might agree that the man move out for a month and participate in a pro-feminist counselling program (for evidence on the effectiveness of such programs, see Dutton et al. 1992; for violent men's reactions to such programs, see Ptacek 1988;

Warters 1993). When conference intervention escalates to taking away the man's home and handing it over to his wife, some will object that this 
amounts to a six-figure fine, higher than the fine any court would impose after due process. But if the man feels an injustice is being done, he can walk away from the conference, allow his warrant(s) to be activated and face any punishment a criminal court may impose. Agreement at a conference to hand over a house is therefore viewed as a consensual civil remedy to the breakdown of a violent relationship rather than as a criminal punishment. While the pyramid strategy represents a preference for solving problems at lower levels before escalating intervention up the pyramid, this is a preference, not a rule. In appropriate contexts, it is necessary to jump levels to go straight to the peak of the pyramid. For example, if a woman will testify against a known serial rapist, he should be routed direct to court and prison. Contrast our regulatory pyramid with what a pro-arrest or mandatory arrest policy yields: routine perfunctory criminal justice processing. One problem with contemporary police practices, noted in Sherman (1992), is that the police tend not to process any differently cases of domestic violence that are the first or the most recent in a repeated pattern of violence. Thus, if the incident is judged not to have caused significant physical injury to the victim, it will be treated similarly, whether it is the first or fifteenth time the woman has called. The idea behind the enforcement pyramid is that intervention is responsive to patterns of offending, where communities of care monitor those patterns with state back-up.

Men who repeatedly batter may ultimately have to be removed from their homes or imprisoned. But to repeat perfunctory arrests while waiting for the victim's luck to run out, waiting for the day when her arrival in the hospital emergency room or the morgue will justify locking him up, is a deplorable policy. Equally, locking up all assailants is unworkable: there are too many for our prisons to accommodate. A policy based on the enforcement pyramid is more practical and more decent. 


\section{Community Conferences and the Pyramid as a Response}

We propose that a response to men's violence against women, which places a heavy, though not exclusive, reliance on community conferences, can address some of the failures in justice system responses. Let us consider each of the three problems.

Problem 1: Most men are not made accountable for acts of rape or violence against intimates. Women do not report rape or intimate violence because they feel ashamed and responsible for the violence; they fear family disintegration, physical reprisal, and being degraded in the courtroom. Institutionalising community conferences provides a means of exposing men's violence without re-victimising women. It is a route of crime control that is not dependent solely on the courage or tenacity of victims. The proposal is unreservedly for net- widening, except it is nets of community rather than state control that are widened. It is important that a court processing option is kept in place; indeed, the community conference option can be managed in such a way as to increase rather than reduce the number of prosecuted rape cases. How could this be? When a woman is concerned with one or more of the above consequences of a criminal trial, she will not continue with the case. But she may be persuaded by police to go with a more private, quicker and less traumatic option of a community conference. At the same time, the police pressure the man to cooperate with the conference, proposing that he may do better and get the matter handled more quickly than if it goes to trial. The conference can proceed without any admission of guilt on the man's part, and he has the right to stop the conference at any point, insisting on his right to have the matters in dispute argued in court. The conference proceeds on the woman's allegations; the man may choose "not to deny" the allegations, though initially may decline to admit guilt. If the conference goes well, it might conclude with the man's admitting guilt and agreeing to sanctions that are less than a court would have imposed, yet more than an absence of sanctions, had the complaint been 
withdrawn. The empirical experience of New Zealand and Australian conferences is that defendants are mostly willing to admit guilt to secure the gentler justice of the conference in preference to the uncertain consequences of a criminal trial. If the conference goes badly (for example, the man refuses to admit his guilt and nothing is settled), the support the woman receives at the conference might embolden her to press charges.

The availability of a community conference option can encourage more women to come forward and to be supported in their victimisation. It may both increase voluntary guilty pleas and supply a support that motivates more victims to proceed to a criminal trial when the defendant denies guilt. It can encourage many women who do report offences, but who do not want to proceed with criminal prosecution, to do something to confront the offender with responsibility for his wrongdoing at a conference. Whether by community conference or trial, increasing numbers of men would be made accountable for their violence against women. When accountability for the guilty becomes a more common outcome of complaint, police should become more willing to define as crime the complaints of rape and violencevictims. Problem 2: The men who are arrested and prosecuted for violence against women have likely got away with it any number of times before and may well have entrenched patterns of raping and assaulting women. When we consider the callousness of some men prosecuted for rape, we may question the plausibility of affecting them through reasoned dialogue and shaming. Equally, we may question the plausibility of deterring them through prison sentences. The objective should be to intervene earlier in these men's lives before they have reached a hardened state. Evidence suggests that abusive men were violent toward family members such as sisters, brothers and mothers when they were young (Straus \& Gelles 1990). However, it should not be forgotten that violence sports, the military and juvenile institutions can also be learning grounds for masculine violence. 
In the New Zealand and Wagga Wagga juvenile programs, the aim is to communicate shame to male adolescents for their very earliest acts of violence. When community conferences become well established, forums are made available to families and concerned citizens for bringing violence and exploitation to light at early stages. The psychologists who dominated criminological thinking until the 1950s were strong advocates of early intervention, a position discredited by 1960s labelling theorists. On balance, we should be pleased that early intervention driven by psychotherapeutic models was defeated.

Republican criminology incorporates the labelling theory critique by calling for a radically different justification for and modality of early intervention: community intervention. One patriarchal legacy of labelling theory is a squeamishness about shaming, a "boys will be boys" approach to violent masculinity. We must distinguish between harmful and productive early intervention. We can and must be early interveners again: we can use the power of shaming to avert patterns of exploitation and degradation of women. This power will be sustained and amplified by a strong women's movement and pro-feminist men's groups.

A conference at Wagga Wagga illustrates the potential for early intervention. It concerned a teenage boy's assault of a teenage girl. Out of the dialogue among participants, it was revealed that the boy had assaulted other girls and had viciously assaulted his mother. Australia has a major problem of teenage boys assaulting their mothers, although one would not know this from media accounts or the scholarly literature, which focus on spouse abuse. While there has been a "breaking of the silence" with spouse assault, this has not occurred for son-mother assault. In a patriarchal culture, it is mothers not sons who feel shame and responsibility for these assaults. Traditional courts and justice system responses offer little chance to break the silence of maternal shame and maternal protectiveness of sons from a punitive justice system. A problem- 
solving dialogue among people who care for both victim and offender, such as occurred at this Wagga Wagga conference, offers a way to break the silence and to confront a violent boy before his patterns become entrenched. Another recent Wagga Wagga conference concerned the sexual assault of a 14year-old girl in a swimming pool by a 14-year-old boy. The victim was most upset by the way the boy had been bragging to his mates, within the victim's hearing, that he had "got one finger in her". The victim was not only revictimised by this humiliation, but also by being labelled as a "dobber" (a "tattle-tale") by boys at her school after she reported the incident. Gossip among her classmates was that she "deserved what she got". Dialogue at the conference clarified that this was not the case. It also made it impossible for the offender's father to believe, as he had before the conference, that his son had been singled out unfairly for a bit of "horseplay". Participants at the conference affirmed her "courage" for coming forward in the face of such social pressures. The offender not only apologised to the victim in a meaningful way, but undertook, together with five other classmates ( 1 male, 4 female) who attended the conference, to spread the word among their peers that her conduct was blameless in every respect, while he took responsibility for his totally unacceptable conduct. In this conference, an exploitative masculinity of 14-year-old boys and an excusing "boys will be boys" fatherly masculinity was confronted by six teenagers and the parents of the victim. Our hypothesis is that this is a better way to confront a misogynist culture than a criminal trial ten years later.

Problem 3: Women victimised by men's violence are re-victimised by engaging the criminal process. One reason rape victims are re- victimised at trial is that criminal trials are transacted in the discourse of stigma (see MacKinnon 1983; Estrich 1986; Smart 1989). Winning is the objective, and each side tries to win through maximum efforts to blacken the adversary's character. The rape trial is a ceremony that puts a highly trained practitioner at 
the defendant's disposal to deny responsibility, to deny injury, and to deny the victim (we draw from Sykes \& Matza's 1957 "techniques of neutralisation" formulation here and below). The rape trial institutionalises incentives for a defendant to reinforce his denials, denials which he believed before the trial, and denials that may have encouraged the rape in the first place (see, for example, Scully \& Marolla 1984, 1985). Faced with prosecutorial vilification of his character, the trained competence to exaggerate evil, the transforming of a partially flawed person into a demon devoid of any redemptive potential, the defendant is ever more equipped to condemn his condemners. If he started the criminal trial in a mood of moral ambivalence toward the victim, he may end up holding the victim and prosecution in utter contempt. The discourse of stigma in rape trials reinforces misogynist masculinities (see also Bumiller 1990). Even if a man is convicted and imprisoned, he will be released eventually, perhaps a more deeply committed and angry misogynist. When fact-finding processes are allowed to stigmatise, disputants slide into a vortex of stigma: stigmatisation is mutually reinforcing. More generally, as Lewis (1971), Scheff (1987), Scheff and Retzinger (1991), and Lansky (1984, 1987) find, when human institutions are designed to foster the by-passing or denial of shame, shame-rage spirals are likely. Justice system procedures promote such spirals.

The community conference is based on different principles. It is designed to minimise stigma. Participants are selected based on their capacity to provide maximum support to victims and offenders, not as in criminal trials, to exert maximum damage to the other side. The aim of community conferences is to reintegrate victim and offender, not to stigmatise.

Compared to the offender-centred criminal trial, community conferences, if managed well, are victim-centred. The victim can confront the offender in her own words in her own way with all the hurt she has suffered, and victim supporters add more. Offenders often admit there were effects they denied or 
had not realised. The aim of the process is to confront the many techniques of neutralisation offenders use. It is to engage in an unconstrained dialogue that leaves responsibility as a fact that is admitted and regretted rather than denied. Victim reintegration can be accomplished by sub-ceremonies following the formal conference. For example, at a conference concerning two boys who had assaulted a boy and girl, the girl said she did not want the offenders to come around to her house to offer a more formal apology because she was still afraid of them. The coordinator asked the girl's family to stay, and in a postconference session, the coordinator discussed what had been said, suggesting that the boys would not come after her or the other victim again. This session ended with the girl agreeing she was no longer afraid. Later, a minister at the girl's church confirmed that the victim reintegration session helped to allay fears and distrusts the girl harboured up until the conference. In contrast to the rape trial, from which a victim can emerge more afraid, frustrated at not having any degree of control, and suffering more reputation damage than the offender, community conferences are designed to empower victims with voice and control. Victims and their supporters have the right to veto the plan of action proposed by offenders and their supporters. Conferences typically conclude with an apology by the offender. This is important for relieving the victim of any taint of blame. The apology can be a much more powerful ceremony than punishment in affirming moral values than have been transgressed, as the contrast between American and Japanese culture attests (Braithwaite 1989; Tavuchis 1991). When an offender rejects any suggestion that the victim may have been at fault and openly condemns the wrongfulness of the act, the censure of crime is reinforced and the cultural support for techniques of neutralisation is eroded.

One wonders how the Clarence Thomas hearings might have gone if American political culture would have allowed Anita Hill's allegations of sexual harassment to be handled in a community conference format. Would it 
not have been better for women if Thomas could have admitted his abusing Hill and apologised for his acts without his being stigmatised and professionally destroyed (Daly 1992)? If after he apologised and stated his commitment to upholding anti-discrimination law, Thomas was then appointed to the court, one wonders whether we would have had a less misogynist US Supreme Court.

When institutions trade in stigma and rule out apology- forgiveness sequences as outcomes, forces of exploitation are uncensored, reinforced, and legitimated. The community conference strategy attempts to break the shamerage spiral, to intervene early in transgressors' lives, and to reintegrate rather than stigmatise victims and offenders.

\section{Questions about the Conference-Pyramid Enforcement Model}

We are advocating an alternative way of responding to men's violence against women. We are not tied to a standard ordering of the pyramid levels, only to the preference for a dynamic problem-solving model. Although our arguments are meant to be suggestively sketched, there are vexing questions about the conference strategy that should beaddressed.

\section{Question 1: Is this just another form of mediation with all of its attendant problems?}

Traditional mediation has been criticised for failing to take violence seriously, lacking procedural accountability, "bar[ring] abused women from access to courts for enforceable protection" (Lerman 1984, p. 72), neutralising conflict by individualising and prophetising grievances (Abel 1982), and failing to deal with the unequal bargaining power of the parties. Balance of power questions will be addressed under Question 2. 
Community conferencing is not like family counselling and traditional victimoffender mediation. The participation of other community members on the basis of special relationships of care for victims and offenders has a transformative effect on the nature of the interaction and on the agreed action plans. David Moore's research on the Wagga Wagga process (private communication with the author) concludes that "more is better" with regard to participants beyond the nuclear family, so long as they are participants who have a relationship of genuine caring with one of the principals.

We agree that traditional mediation hands unaccountable power to mediation professionals whose "assumptions about the nature and seriousness of family violence" (Lerman 1984, p. 72) should be open to public scrutiny. We agree that it is wrong to bar women from access to courts for enforceable protection. Accountability to the courts should be guaranteed for both sides. Victims, like defendants, should have the right to withdraw from a conference and insist on activating an arrest warrant. Accountability to courts is not the most important accountability, however. Accountability to those citizens who have concern for victims and offenders is the more deeply democratic form of accountability (Barber 1984; Dryzek 1990). The traditional justice process "steals conflicts" from citizens (Christie 1977), keeping victims and offenders apart. The community conference requires victims and offenders to confront their conflict, without neutralising their emotions.

We agree that traditional mediation risks a limited, prophesied justice. Scutt (1988, p. 516) argues that privatisation of justice is detrimental to the interests of the disadvantaged when it "shuts off from public view the very nature of the inequality from which the individual and group suffer" (see also 
Allen 1985; Hatty 1985). In contrast to mediation, conferences are designed to encourage community dialogue on intimate violence.

Private justice does risk rendering "the personal apolitical" in the traditional dyadic form of offender and victim, mediated by a professional. Traditional public justice hardly does better in grappling with domination: it silences communities of concern by the disempowering roles of legal professionals (Snider 1990). The important question is not whether private or public justice is the bigger failure in communicating censure. It is how to redesign both, and the dynamic interplay between them, so that incidents of violence become occasions for community debates about brutalising masculinities and inequalities spawning violence.

\section{Question 2: Can we expect "communities of concern" to be any less sexist or misogynist than traditional justice system responses or state intervention?}

Some will think it naive that communitarian dialogue can work in places like Australia, where one-fifth of survey respondents agree that it is acceptable under some circumstances for a man to hit his wife (Public Policy Research Centre 1988). It is not naive precisely because four-fifths do not find such violence acceptable. The problem is that one-fifth are able to erect walls around the private space of the family to protect themselves from the disapproval of the four-fifths. Even if many of these four-fifths "condemn wife beating, and yet at the same time actively support the type of marital relationship that encourages it" (Dobash \& Dobash 1979, p. 179), at least their condemnation can be harnessed in conferences.

Voices in defence of exploitation and brutality will be heard in community conferences. But exploitation and brutality flourish more in secretive settings, when they go unchallenged and unnoticed (Hopkins \& McGregor 1991, p. 127). When intimate violence is noticed and challenged, rationalisations sustained in secret settings are opened to dialogue. It would not be possible to have regulatory institutions where only feminist voices 
were heard and misogynist voices were completely silenced. However, dialogic institutions favour parties who are on the moral high ground, and feminists are clearly on the high ground. So we suspect that conferences can create spaces to advance struggles for feminist voices to be heard against those of misogynists. As a flexible process of community empowerment, conferences permit more latitude for redressing power imbalances than the inflexible procedures of the court. Balance can be restored by the collective might of a victim's supporters (as in the case of the Wagga Wagga teenagers who supported their friend after she was sexually assaulted). It can be restored by powerful men, for example, a doctor, a brother, an uncle, a teacher, a neighbour, who subscribe to an anti-violent masculinity and who are more than a match for a domineering husband. Women can create institutions that give male allies a chance to show their mettle. Power imbalance can be most effectively restored by organised feminists who work as shelter advocates. Here, one strength of our proposal is that a shift in resources from police lockups to shelters can provide a base for feminist organisation. Improved criminal justice institutions are no substitute for a stronger women's movement as the keystone to controlling violence against women. In the meantime, we can design criminal justice institutions to enfranchise voices from the women's movement, coupled with those of abused women and caring men.

Conference coordinators need training to be effective in organising conferences that are responsive to men's violence against women. Training could include speakers from the women's movement and shelters, and role playing of conference scenarios subject to feminist interpretations. Coordinators can readily be required to hear feminist voices during inservice training, while it may take longer to require judges to do so.

\section{Question 3: Do conferences work? Are participants satisfied?}

Evaluation of conferences for juvenile cases in New Zealand (Maxwell \& Morris 1993; Morris \& Maxwell 1993) suggests "there is much that is 
positive and novel about [this] system of youth justice" (Morris \& Maxwell 1993, p. 88), including the diversion of most juveniles away from courts and institutions, involvement of families in decisions and taking responsibility, and acknowledgment of differences in cultural groups. The authors cite these problems, however: professionals often took over the process, adolescent offenders often did not feel involved, and just half of victims said they were satisfied with the outcome. Levels of satisfaction with conference outcomes were substantially higher for offenders and family members ( 85 per cent) than for victims (51 per cent) (Maxwell \& Morris 1993, p. 115-20). Victim dissatisfaction was explained by:

inadequate conference preparation ... about what to expect ... and unrealistic expectations [for] likely . . . outcomes, especially with respect to reparation (Morris \& Maxwell 1993, p. 86).

More research is needed and more is underway. In particular, we need methodologically sound outcome evaluations (from both juvenile and adult samples) on whether violence falls following conferences more than it does following criminal trials.

We do not wish to hide implementation failures of conferences in New Zealand or Wagga Wagga, the difficulties of struggling against domination and stigma, nor would we suggest that conferences are a panacea even when perfectly implemented. We are suggesting that community conferences open an avenue for addressing the failures of contemporary justice processes, which leave misogynist masculinities untouched by shame and victims scarred by blame.

\section{Conclusions}

Men's violence against women is a crime enabled by men's domination (Daly \& Wilson 1988; Dobash \& Dobash 1979; Evason 1982; Yllo \& Straus 1990). Republican and feminist theory (Braithwaite 1991, 1993; Yllo \& Bograd 1988; MacKinnon 1983) argue that a reduction in men's violence toward 
women will occur when gender inequality is reduced and when human social bonds are more caring. There are many ways of causing cracks in patriarchal structures that have barely been discussed here. Among the most central are transforming economic power, familial, and sexual relations toward greater gender equity and strengthening the political power of the women's movement and pro-feminist elements in other liberation movements. Contemporary criminal justice practices may do more to cement over cracks in patriarchal structures than prise them open. Current practices leave patriarchal masculinities untouched and victims more degraded and defeated; and to continue with more of the same policies may make things worse. This is not to deny a role for the criminalisation of violence and state intervention of the kind envisaged in the enforcement pyramid.

We have proposed an alternative way of thinking about responding to men's violence against women that is based on these ideas:

- the threat of escalated state intervention (formalism) can empower more effective communitarian intervention (in formalism);

- ceremonies can centre on reintegrative shaming of offenders and reintegrative caring for victims;

- communities of care can devise their own preventive strategies, and can be motivated to implement them by their affection and attachment to particular victims and offenders; and

- dialogue can be sustained within communities of care about the rejection of violent masculinities and, more optimistically, about the search for non-violent masculinities.

While non-exploitative masculinities have the potential to emerge in community conferences, their expression is largely foreclosed in courtrooms and prisons. The creation of institutions that require men to listen to women and that open spaces for apology and dialogue might clear the way for a collective wisdom to emerge. That communal wisdom may redefine 
masculinities beyond the wit of our individual imaginings. Though it may not be possible to design criminal justice institutions that prevent violence, we can fashion institutions that generate less violence. 


\section{References}

Abel, R. 1982 (ed.), The Politics of Informal Justice, Academic Press, New York.

Adler, Z. 1987, Rape on Trial, Routledge and Kegan Paul, London.

Alder, C. 1991, "Explaining violence: Socioeconomics and masculinity", in Australian Violence: Contemporary Perspectives, eds. D. Chappell, P. Grabosky \& H. Strang, Australian Institute of Criminology, Canberra.

Alder, C. \& Wundersitz, J. 1994, Family Conferencing and Juvenile Justice: The Way Forward or Misplaced Optimism?, Australian Institute of Criminology, Canberra.

Allen, J. 1985, "Desperately seeking solutions: Changing battered women's options since 1880", in National Conference on Domestic Violence, ed. S.E. Hatty, vol. 1, Australian Institute of Criminology, Canberra.

Ayres, I. \& Braithwaite, J. 1992, Responsive Regulation: Transcending the Deregulation Debate, Oxford University Press, New York.

Barber, B. 1984, Strong Democracy: Participatory Politics for a New Age, University of California Press, Berkeley.

Berk, R.A. \& Sherman, L.W. 1985, "Data collection strategies in the Minneapolis domestic assault experiment", in Collecting Evaluation Data: Problems and Solutions, eds. L. Burstein, H.E. Freeman \& P.H. Rossi, Sage, Newbury Park CA, pp. 35-48.

The Black Scholar 1992 (ed.), Court of Appeal: The Black Community Speaks Out on the Racial and Sexual Politics of Thomas vs. Hill, Ballantine Books, New York.

Bowman, C. 1992, "The arrest experiments: A feminist critique", Journal of Criminal Law and Criminology, no. 83, pp. 201-8.

Braithwaite, J. 1989, Crime, Shame and Reintegration, Cambridge University Press, Sydney.

1991, "Poverty, power, white-collar crime and the paradoxes of criminological theory", Australian and New Zealand Journal of Criminology, no. 24, pp. 40-58.

1993, "Inequality and republican criminology" in Inequality and Crime, eds.

J. Hagan \& R. Petersen, Stanford University Press, Palo Alto.

Braithwaite, J. \& Mugford, S. 1994, "Conditions of successful reintegration ceremonies: Dealing with juvenile offenders", British Journal of Criminology, vol. 34, no. 2, pp. 139-71.

Braithwaite, J. \& Pettit, P. 1990, Not Just Deserts: A Republican Theory of Criminal Justice, Oxford University Press, Oxford.

Bridgeforth, C.A. 1990, Predicting Domestic Violence from Post-Arrest Suspect 
Interviews, MA Thesis, Institute of Criminal Justice and Criminology, University of Maryland.

Brownmiller, S. 1975, Against Our Will: Men, Women and Rape, Penguin, Melbourne.

Bumiller, K. 1990, "Fallen angels: The representation of violence against women in legal culture", International Journal of the Sociology of Law, no. 18, pp. 125-42.

Bureau of Justice Statistics 1987, "Sentencing Outcomes in 28 Felony Courts 1985", NCJ-105743, US Department of Justice, Washington, DC.

Buzawa, E. \& Buzawa, C. 1990, Domestic Violence, Sage, Newbury Park, California. Carrigan, T., Connell, R.W. \& Lee, J. 1985, "Toward a new sociology of masculinity", Theory and Society, vol. 14, pp. 551-604.

Chappell, D. \& Singer, S. 1977, "Rape in New York city: A study of material in the police files and its meaning", in Forcible Rape: The Crime, The Victim and the Offender, eds. D. Chappell, R. Geis \& G. Geis, Columbia University Press, New York.

Chaudhuri, M. \& Daly, K. 1992, "Do restraining orders help? Battered women's experience with male violence and legal process", in Domestic Violence: The Changing Criminal Justice Response, eds. E.S. Buzawa \& C.G. Buzawa, Auburn House, Westport, CT, pp. 227-52.

Christie, N. 1977, "Conflict as property", British Journal of Criminology, no. 17, pp. 126.

Connell, R.W. 1987, Gender and Power, Stanford University Press, Stanford.

Daly, K. 1992, "What would have been justice?" Remarks to Plenary on Sexual Harassment in the Thomas Hearings, Law and Society Association Annual Meeting.

Daly, M. \& Wilson, M. 1988, Homicide, Aldine de Gruyter, New York.

Dobash, R.E. \& Dobash, R.P. 1979, Violence Against Wives, The Free Press, New York.

1992, Women, Violence and Social Change, Routledge and Kegan Paul, London.

Dryzek, J. 1990, Discursive Democracy, Cambridge University Press, Cambridge.

Dunford, F. 1990, "System-initiated warrants for suspects of misdemeanor domestic assault: A pilot study", Justice Quarterly, no. 7, pp. 631-53.

Dutton, D. 1988, The Domestic Assault of Women: Psychological and Criminal Justice Perspective, Allyn \& Bacon, Boston.

Dutton, D.G., Hart, S.D., Kennedy, L.W. \& Williams, K.R. 1992, "Arrest and the reduction of repeat wife assault", in Domestic Violence: The Changing Criminal 
Justice Response, eds. E.S. Buzawa \& C.G. Buzawa, Auburn House, Westport CT, pp. 111-27.

Edwards, S. 1989, Policing Domestic Violence: Women, the Law and the State, Sage, Newbury Park, California.

Eijkman, H. 1992, "Police, victims and democracy: Rewriting the priorities," in

Policing Australia: Old Issues, New Perspectives, eds. P. Moir \& H. Eijkman, Macmillan, Melbourne.

Estrich, S. 1986, "Rape", The Yale Law Journal, no. 95, pp. 1087-184.

1987, Real Rape, Harvard University Press, Cambridge, Massachusetts.

Evason, E. 1982, Hidden Violence, Farset Press, Belfast.

Fagan, J. \& Browne, A. 1990, Violence Towards Intimates and Spouses, report commissioned by the Panel on the Understanding and Control of Violent Behavior, National Research Council, National Academy of Sciences, Washington, DC.

Ferraro, K.J. 1989, "Policing woman battering", Social Problems, no. 36, pp. 61-74.

Ferraro, K.J. \& Boychuk, T. 1992, "The court's response to interpersonal violence:

A comparison of intimate and nonintimate assault", in Domestic Violence: The Changing Criminal Justice Response, eds. E.S. Buzawa \& C.G. Buzawa, Auburn House, Westport CT, pp. 209-25.

Fineman, M, 1991, The Illusion of Equality: The Rhetoric and Reality of Divorce Reform, The University of Chicago Press, Chicago.

Frieze, I.H. \& Browne, A. 1989, "Violence in marriage", in Family Violence, eds. L. Ohlin \& M. Tonry, The University of Chicago Press, Chicago, pp. 163-218.

Frisch, L.A. 1992, "Research that succeeds, policies that fail", Journal of Criminal Law and Criminology, no. 83, pp. 209-16.

Frohmann, L. 1991, "Discrediting victims' allegations of sexual assault: prosecutorial accounts of case rejections", Social Problems, no. 38, pp. 213-26.

Hatty, S. 1985, "On the reproduction of misogyny: The therapeutic management of violence against women", in National Conference on Domestic Violence, ed. S.E. Hatty, vol. 1, Australian Institute of Criminology, Canberra. 1988, Male Violence and the Police: An Australian Experience, School of Social Work, University of New South Wales, Sydney.

Hirschel, J.D., Hutchinson, I.W. III, Dean, C., Kelley, J.J. \& Pesackis, C.E. 1990, Charlotte Spouse Assault Replication Project: Final Report, National Institute of Justice, Washington, D.C.

Hopkins, A. \& McGregor, H. 1991, Working for Change: The Movement Against Domestic Violence, Allen and Unwin, Sydney. 
Kalven, H. \& Zeisel, H. 1966, The American Jury, University of Chicago Press, Chicago.

Katz, J. 1988, "Seductions of crime: Moral and sensual attractions", in Doing Evil, Basic Books Inc., New York.

Lansky, M. 1984, "Violence, shame and the family", International Journal of Family Psychiatry, no. 5, pp. 21-40.

1987, "Shame and domestic violence", in The Many Faces of Shame, ed. D.

Nathanson, Guildford, New York.

Lasch, C. 1977, Haven in a Heartless World, Basic Books, New York.

Lempert, R.O. 1989, "Humility is a virtue: On the publication of policy-relevant research", Law \& Society Review, no. 23, pp. 145-61.

Lerman, L.G. 1984, "Mediation of wife abuse cases: The adverse impact of informal dispute resolution on women", Harvard Women's Law Journal, no. 7, pp. 57-113. 1992, "The decontextualization of domestic violence", Journal of Criminal Law and Criminology, no. 83, pp. 217-40.

Lewis, H.B. 1971, Shame and Guilt in Neurosis, International Universities Press, New York.

Luckenbill, D.F. 1977, "Criminal homicide as situated transaction", Social Problems, no. 26 , pp. $176-86$.

MacKinnon, C. 1983, "Feminism, Marxism, method, and the state: An agenda for theory", Signs: Journal of Women in Culture and Society, no. 8, pp. 635-58.

--------- 1987, Feminism Unmodified: Discourses on Life and Law, Harvard University Press, Cambridge, Massachusetts.

Maxwell, G.M. \& Morris, A. 1993, Family Victims and Culture: Youth Justice in N.Z., Institute of Criminology, Victoria University of Wellington, Wellington.

Meima, M. 1990, "Sexual violence, criminal law and abolitionism", in Gender, Sexuality and Social Control, The European Group for the Study of Deviance and Social Control, eds. B. Rolston \& M. Tomlinson, Bristol, England, pp. 238-52.

Miedzian, M. 1991, Boys Will Be Boys: Breaking the Link Between Masculinity and Violence, Doubleday, New York.

Ministerial Review Team to the Minister of Social Welfare 1992, Review of the Children, Young Persons and their Families Act, 1989, Minister of Social Welfare, Wellington.

Morris, A. \& Maxwell, G.M. 1993, "Juvenile justice in New Zealand: A new paradigm", Australian and New Zealand Journal of Criminology, no. 26, pp. 72 90.

Morrison, T. 1992 (ed.), Race-ing Justice, En-gendering Power: Essays on Anita Hill, 
Clarence Thomas, and the Construction of Social Reality, Pantheon Books, New York.

Mugford, J. \& Mugford, S. 1992, "Policing domestic violence" in Policing Australia: Old Issues, New Perspectives, eds. P. Moir \& H. Eijkman, Macmillan, Melbourne. Newby, L. 1980, "Rape victims in court: The Western Australian example", in Rape Law Reform, ed. J.A. Scutt, Australian Institute of Criminology, Canberra.

Office of the Commissioner for Children 1991, An Appraisal of the First Year of the Children, Young Persons and Their Families Act 1989, briefing paper, Office of the Commissioner for Children, Wellington, New Zealand.

Polk, K. \& Ranson, D. 1991, "Homicide in Victoria", in Australian Violence: Contemporary Perspectives, eds. D. Chappell, P. Grabosky \& H. Strang, Australian Institute of Criminology, Canberra.

Ptacek, J. 1988, "Why do men batter their wives?", in Feminist Perspectives on Wife Abuse, eds. K. Yllo \& M. Bograd, Sage, Newbury Park, CA, pp. 133-57.

Public Policy Research Centre 1988, Domestic Violence Attitude Survey, conducted for the Office of the Status of Women, Department of Prime Minister and Cabinet, Canberra.

Real Rape Law Coalition 1991, "Sexual assault: The law v. women's experience", in Rape: Reform of Law and Procedure, Law Reform Commission of Victoria, Appendices to Interim Report No. 42, Melbourne.

Retzinger, S.M. 1991, Violent Emotions: Shame and Rage in Marital Quarrels, Sage, Newbury Park.

Rifkin, J. 1989, "Mediation in the justice system: A paradox for women", Women \& Criminal Justice, no. 1, pp. 41-54.

Scheff, T.J. 1987, "The shame-rage spiral: A case study of an interminable quarrel", in The Role of Shame in Symptom Formation, ed. H.B. Lewis, LEA, Hillside, New Jersey.

Scheff, T.J. \& Retzinger, S.M. 1991, Emotions and Violence. Shame and Rage in Destructive Conflicts, Lexington Books, Lexington.

Scully, D. \& Marolla, J. 1984, "Convicted rapists' vocabulary of motive: excuses and justifications", Social Problems, no. 31, pp. 530-44.

1985, "Riding the bull at Gilley's: Convicted rapists describe the rewards of rape", Social Problems, no. 32, pp. 251-63.

Scutt, J. 1983, Even in the Best of Homes: Violence in the Family, Penguin, Melbourne.

1988, "The privatization of justice: Power differentials, inequality, and the palliative of counselling and mediation", Women's Studies Forum, no. 11, pp. 
503- 20.

Sherman, L.W. 1992, Policing Domestic Violence: Experiments and Dilemmas, Free Press, New York.

1993, "Defiance, deterrence and irrelevance: A theory of the criminal sanction", Journal of Research in Crime and Delinquency, vol. 30, no. 4, pp. 44573.

Sherman, L.W. \& Berk, R.A. 1984, "The specific deterrence effects of arrest for domestic assault", American Sociological Review, no. 49, pp. 261-72.

Smart, C. 1989, Feminism and the Power of Law, Routledge, London.

1990, "Law's truth/women's experience" in Dissenting Opinions: Feminist Explorations in Law and Society, R. Graycar, Allen and Unwin, Sydney.

Smith, L. 1989, Concerns About Rape, Her Majesty's Stationery Office, London.

Smith, M.D. 1990, "Patriarchal ideology and wife beating: A test of a feminist hypothesis", Violence and Victims, no. 5, pp. 257-73.

Snider, L. 1990, "The potential of the criminal justice system to promote feminist concerns", Studies in Law Politics and Society, no. 10, pp. 143-72.

1992, "Feminism, punishment and the potential of empowerment". Submitted to Canadian Journal of Law and Society.

Stanko, E.A. 1982, "Would you believe this woman? Prosecutorial screening for 'credible' witnesses and a problem of justice", in Judge. Lawyer, Victim, Thief, eds.

N.H. Rafter \& E.A. Stanko, Northeastern University Press, Boston, pp. 63-82.

1985, Intimate Intrusions: Women's Experience of Male Violence, Routledge and Kegan Paul, London.

1989 "Missing the mark? Policing battering" in Women, Policing, and Male

Violence: International Perspectives, eds. J. Hamner, E.A. Radford \& E.A. Stanko, Routledge and Kegan Paul, London.

Stith, S.M. 1990, "Police response to domestic violence: The influence of individual and familial factors", Violence and Victims, no. 5, pp. 37-49.

Straus, M.A. \& Gelles, R.J. 1990, Physical Violence in American Families, Transaction Publishers, New Brunswick, New Jersey.

Sykes, G. \& Matza, D. 1957 "Techniques of neutralization: A theory of delinquency", American Sociological Review, no. 22, pp. 664-70.

Tavuchis, N. 1991, Mea Culpa: A Sociology of Apology and Reconciliation, Stanford University Press, Stanford.

Temkin, J. 1987, Rape and the Legal Process, Sweet and Maxwell, London. Warters, W.C. 1993 (unpub.), Collisions with feminism: Perspectives of abusive men 
who've been challenged to change, Department of Sociology, Syracuse University. Williams, K.R. \& Hawkins, R. 1989, "The meaning of arrest for wife assault", Criminology, no. 27, pp. 163-81.

Wilson, P. 1978, The Other Side of Rape, University of Queensland Press, St. Lucia, Queensland.

Yllo, K.A. \& Bograd, M. 1988 (eds.), Feminist Perspectives on Wife Abuse, Sage, Newbury Park.

Yllo, K.A. \& Straus, M.A. 1990, "Patriarchy and violence against wives: The impact of structural and normative factors", in Physical Violence in American Families, eds.

M.A. Straus \& R.J. Gelles, Transaction Publishers, New Brunswick, New Jersey. Zaretsky, E. 1976, Capitalism, the Family, and Personal Life, Harper \& Row, New York.

Zorza, J. 1992, "The criminal law of misdemeanour domestic violence", Journal of Criminal Law and Criminology, no. 83, pp. 46-72. 


\section{Figure 1}

\section{Domestic Violence Enforcement Pyramid}

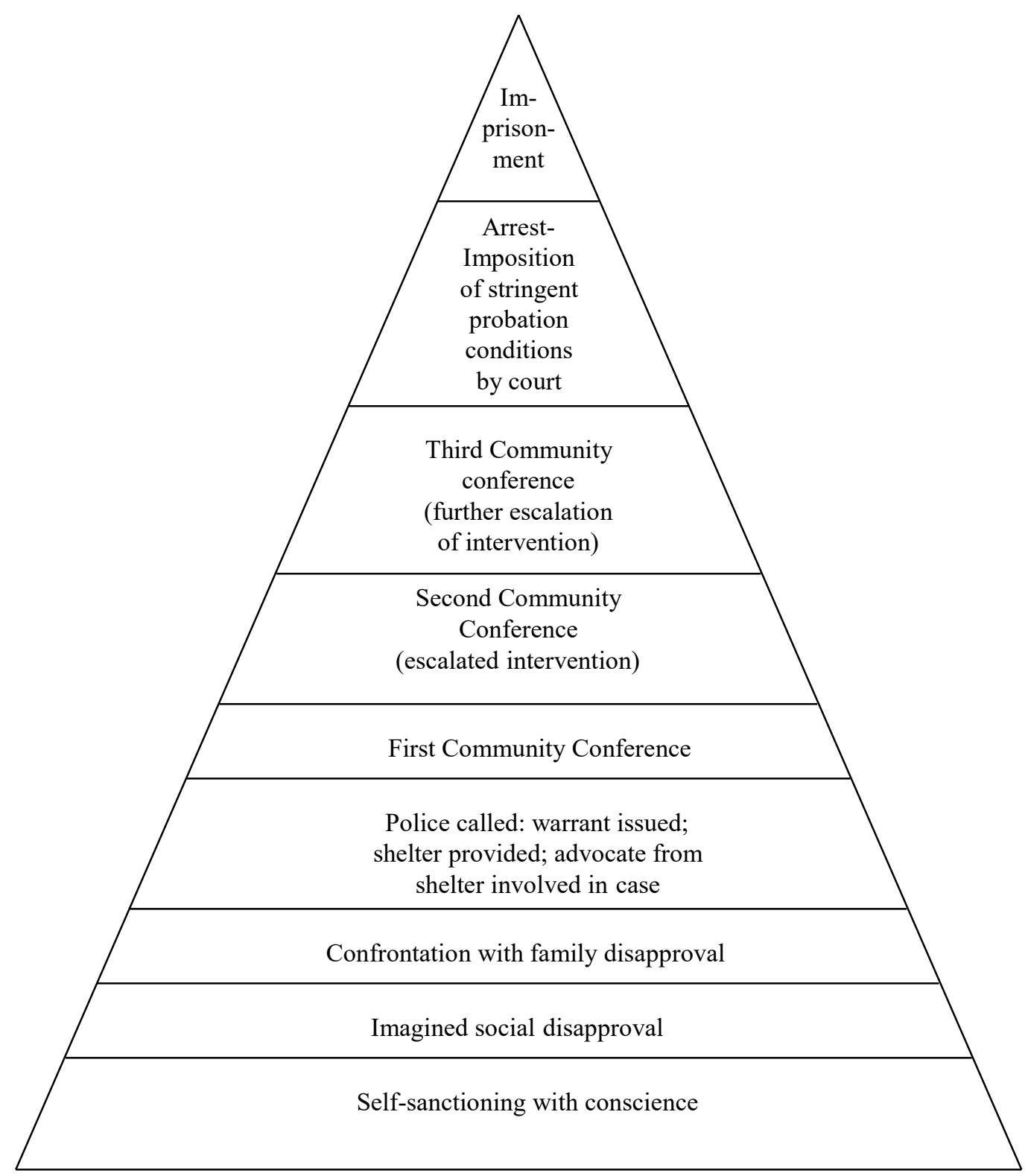

